\title{
表面疲労亀裂検出に対する各種非破壊試験の適用性
}

\section{FEASIBILITY STUDY ON DETECTION OF FATIGUE CRACK IN FILLET WELDED JOINT}

\author{
三木干寿* ·深沢誠**・加藤昌彦***・大畦久雄**** \\ By Chitosi MIKI, Makoto FUKAZAWA, Masahiko KATOH and Hisao OHUNE
}

\begin{abstract}
The crack detection ability was compared and investigated using various nondestructive testing methods on the fatigue cracks generated on the fillet welded joint. As a result, for the detection of cracks, the magnaflux examination and the eddy cullent examination were found effective. However, in the case of dye penetrant examination, even wide cracks on plate surface could not be detected. On the other hand, for the estimation of the crack depth, the peak echo method using the ultrasonic examination was found excellent, allowing the detection of cracks with depth larger than $2.5 \mathrm{~mm}$, with an accuracy of better than $1 \mathrm{~mm}$.
\end{abstract}

Keywords : non-destructive testing, fatigue crack, fillet welded jaint

\section{1. 緒言}

近年，鋼橋の部材に疲労亀裂の発生している事例がか なり報告されているが(1) 4), そのうち特に, ウェブギャッ プ（ウェブに取り付けられた横桁や垂直補剛材の端部と フランジとの間に残されたわずかなギャップ）の面外変 形に起因する隅肉溶接継手の疲労亀裂の例が多( ${ }^{5)}$. こ のような疲労亀裂の発生は橋梁構造物の中ではきわめて 局部的な現象であり，橋梁としての強度にただちに影響 を与えるものではないが，長期間放置しておくと重大な 破壊に進展するおそれがある。したがって，それらを早 い時期に発見し，適切な補修を行うことが重要である. 現在では破壊力学を適用することにより, 補修の要否, 補修期間の設定のための寿命予測などを定量的に評価す ることが可能であり ${ }^{6), 7)}$, この場合, 疲労亀裂を確実に 検出すること，および精度よくその寸法を測定すること が必要となる.

橋梁の現場での検查において最も多く用いられ，信頼

* 正会員 工博 東京工業大学土木工学科 （₹152 目黒区大岡山 2-12-1）

** 正会員 (株横河橋梁製作所（干260 千葉市新港 88）

*** 正会員 中国エックス線侏)（テ737 広島県吳市 3 条 2-4-10）

***** 正会員 関西エックス線 (株)

(厂733 広島市西区南観音 4-5-11)
できる方法は熟練者による目視検査とされている ${ }^{8), 9)}$. 大部分の亀裂は目視によって錆汁を伴った塗膜の割れと して検出され, その後, 主に浸透探傷試験を主とする非 破壊検査が適用される。この場合, 疲労亀裂はきわめて シャープであり, 表面亀裂の場合でもほとんど開口して おらず，亀裂がないものと判断されることがある．溶接 欠陷に対する非破壊試験についてはすでに十分な経験と データの蓄積があるが(10),11), 疲労亀裂に関するものは少 なく, 特に橋梁の現場での非破壊検査の系統だった検討 となるとアメリカ合衆国の NCHRP の Project として 行われた例のみである ${ }^{9)}$. そこで，本試験では，既設橋 梁の現場検査としての各種非破壊試験の適用性および限 界を明らかにする目的で, 面外変形によって隅肉溶接止 端部から発生する疲労亀裂を対象として，それぞれの非 破壊試験について最も適した探傷条件を選ぶとともに， 亀裂検出限界および精度を比較検討する。

\section{2. 供試体および試験方法}

試験には隅肉溶接疲労供試体を用いた。図一 1 に供試 体形状を示す. 前面隅肉溶接を対象とした供試体 $\mathrm{A}$ と, 回し溶接部を対象とした供試体 B の 2 シリーズである. 主材 (SM 58 Q) の幅は 50〜 $65 \mathrm{~mm}$, 板厚は 9〜24 mm であり, いずれも 4 点曲げ繰返し載荷により止端部から 


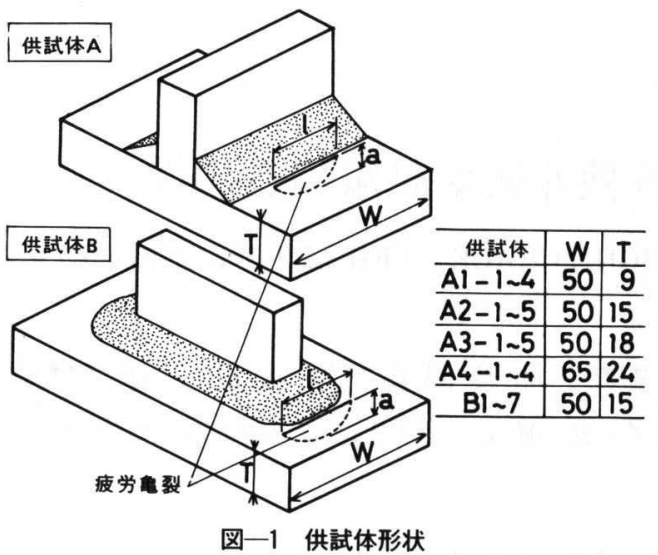

種々の大きさの亀裂を発生させてある.ここで, 供試体 A は隅肉溶接一般部の止端から発生する亀裂をモデル 化したものであり, 供試体 B は垂直補剛材下端の回し 溶接止端部から発生する亀裂に相当する.

非破壊試験はまず, 磁粉探傷試験, 渦流探傷試験, 浸 透探傷試験を行い, 表面での亀裂長さ $(l)$ を推定した. 引き続き, 亀裂の存在が確認された部位について超音波 探傷試験を行い, 亀裂深さ $(a)$ を推定した. 亀裂深さ についてはあらかじめ幅方向での適当な位置を設定し

( 1 ～ 3 か所), その位置での深さを求めた. これらの 非破壊試験の終了後, 亀裂破面を露呈して推定值と実寸 法との対応を検討した。 なお, それぞれの供試体の実亀 裂寸法は付表一1，付表一2に示す，B6, B7 については リブ板側止端部から亀裂が発生しているが, 他の亀裂と 同様に主材方向に進展していることから，寸法推定にあ たっては区別しなかった.

\section{3. 各種非破壊試験による表面曹裂の探傷}

素材および溶接部の欠陥を検査する目的で種々の非破 壊試験方法が開発され, 実用化されている。このうち橋 梁の現場での検査といった観点からは使用可能な非破壊 試験方法は限られている。ここでは, 簡便に適用が考え られる磁粉探傷試験, 渦流探傷試験, 浸透探傷試験につ いて検討した。

\section{（1）探傷条件の選定}

それぞれの非破壊試験について予備実験を行い，亀裂 検出性能, 作業性を考慮した適切な探傷条件を設定した。

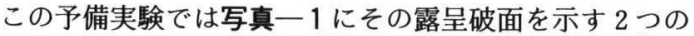
亀裂（A 2-1, A 2-3）について行ったが, 深さが大きい A2-1 の亀裂（最大深さ； $9.7 \mathrm{~mm}$ ) の場合にはいずれの 試験方法および探傷条件でも検出が可能であった。 そこ で，主に比較的小さな亀裂（最大深さ; $2.5 \mathrm{~mm}$ ) につ いて適正条件の検討を行った。

まず, 磁化方法, 磁化電流, 磁粉の種類を変えて行っ
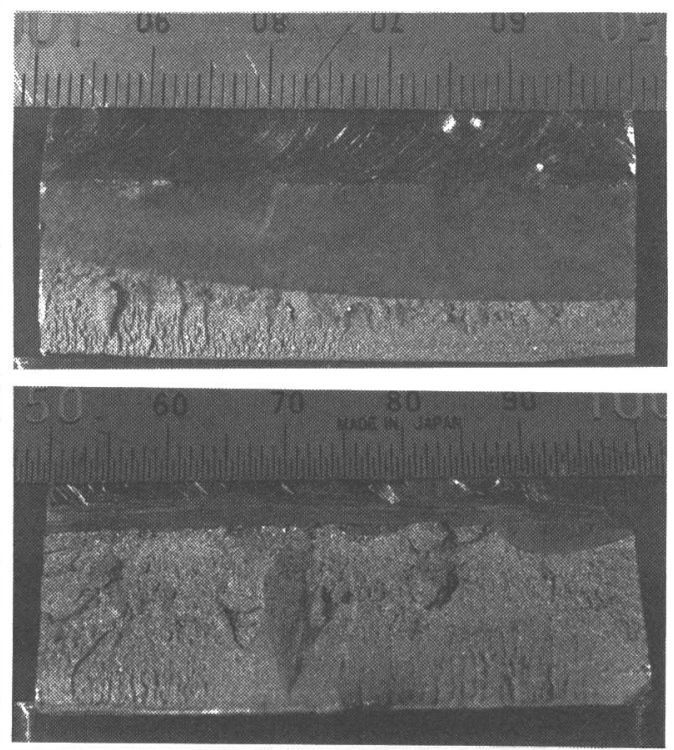

写真一1 予備実験に用いた疲労㫣裂破面 (上:A2-1, 下:A2-3)

表一1 各種磁粉探傷試験の奄裂検出能力

\begin{tabular}{|c|c|c|c|}
\hline 磁化方法 & 磁化電流 & 磁粉 & 検出性能 \\
\hline \multirow{2}{*}{ 極間法 } & \multirow{2}{*}{ 交 流 } & 䡎式非蛍光 & $x$ \\
\hline & & 湿式蛍光 & 0 \\
\hline \multirow{4}{*}{ プロッド法 } & \multirow{2}{*}{ 交 流 } & 䡎式非蛍光 & $x$ \\
\hline & & 湿式蛍光 & 0 \\
\hline & \multirow[t]{2}{*}{ 直 流 } & 䡎式非蛍光 & $x$ \\
\hline & & 湿式蛍光 & $\mathrm{O}$ \\
\hline
\end{tabular}

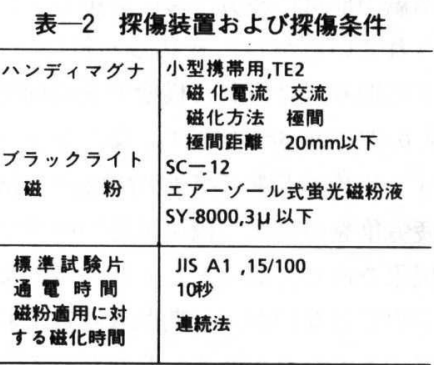

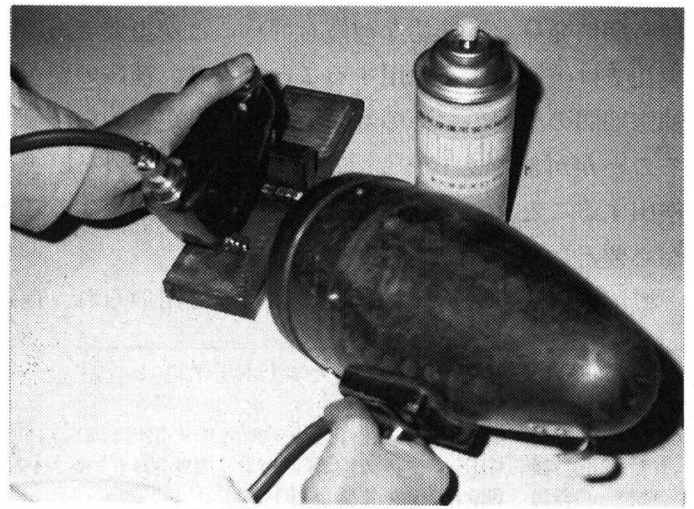

写真一2 磁䎦探佰試験状況 
た磁粉探傷試験の結果を表一1に示す. 極間法, プロッ ド法とも, 亀裂検出能力は乾式非蛍光よりも湿式蛍光が 優れている. また, 実橋での検査の作業能率を考えると, プロッド法は極間距離の設定, アークストライク発生防 止などの磁化操作が煩雑であり可搬性も悪く, 蛍光湿式 交流極間法が最も適している.そこで, 試験は表一2に 示す使用装置および探傷条件で行った. なお, 写真一2 には探傷状況を示す。

次に, 自己比較方式 (差動コイルサーフェイスタイプ) と単一方式について行った渦流探傷試験の結果を表一3 に示す. A 2-1 は亀裂深さが大きく, いずれの条件でも 亀裂の存在が確認できた。しかしながら, A2-3につい ては自己比較方式では検出できなかった．この亀裂は長 さが $12 \mathrm{~mm}$ であり, 試験片端面にまで進展している.

コイルの形状，材質の相異から，自己比較方式は単一方 式に比べて端面効果によるノイズ (疑似信号) の発生範 囲が広く，亀裂信号が探知できなかったものと考えられ る.この端面効果は今回の試験片特有のものであり, 実 橋部材ではほとんど考える必要がないが, 試験において は, 疑似信号の少ない単一方式が適していると判断した。 表一 4 に探傷条件を, 写真一 3 に探傷状況を示す.

\section{表一3 各種渦流探傷試験の軎裂検出能力}

\begin{tabular}{|c|c|c|c|c|}
\hline \multicolumn{3}{|c|}{ 探愎条件 } & \multicolumn{2}{|c|}{ 検出性能 } \\
\hline 装貫 & 使用コイル & 周波数 & A2-1 & $A 2-3$ \\
\hline \multirow{3}{*}{ ED800 } & \multirow{3}{*}{$\begin{array}{l}\text { 自己比輬方法 } \\
\text { 空心 : } 9 \phi \\
\text { 鉄心丸㮖: } 14 \phi\end{array}$} & $10 \mathrm{KHz}_{\mathrm{Z}}$ & $\mathrm{O}$ & $x$ \\
\hline & & $30 \mathrm{KH}_{\mathrm{Z}}$ & $\mathrm{O}$ & $x$ \\
\hline & & $60 \mathrm{KH}_{2}$ & $\mathrm{O}$ & $x$ \\
\hline AMKEC & 単一方法 & & & \\
\hline MK IX & 鉄心馬䟲形 & $5 \mathrm{KHz}$ & 0 & 0 \\
\hline Type C & 外形寸法: $10 \mathrm{~mm}$ & & & \\
\hline
\end{tabular}

\begin{tabular}{|c|c|}
\hline $\begin{array}{l}\text { 探 傷器 } \\
\text { ブローフ }\end{array}$ & $\begin{array}{l}\text { AMLEC MK IX Type C } \\
\text { 缺心馬蹄形，外形寸法: } 10 \mathrm{~mm}\end{array}$ \\
\hline $\begin{array}{l}\text { 対比試験片 } \\
\text { 試駼周波数 } \\
\text { 探筑感度 }\end{array}$ & $\begin{array}{l}\text { スリット試験片, } 0.2 \mathrm{~W} \times 1.0 \mathrm{H} \times 10 \\
5 \mathrm{KHZ} \\
\text { スリット部が検出可能な感度を最低 } \\
\text { レヘルとし、実探但感度は健全部の } \\
\text { 溶接止端部で異常を示さない感度と } \\
\text { する。。 }\end{array}$ \\
\hline
\end{tabular}

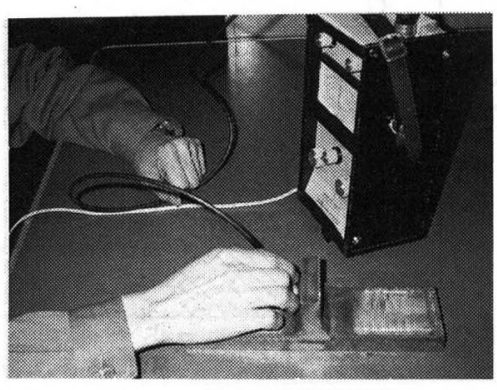

写真一3 渦流探傷試験状況
浸透探傷試験として，一般に溶剤除去性染色浸透探傷 法と水洗性蛍光浸透探傷法の 2 種類が挙げられる. 微小 亀裂の検出に対しては，鮮明な指示模様を示すことから 水洗性蛍光浸透探傷の方が優れていたが，水道，電源な どの使用設備および作業能率の点から, 現場でのより簡 便な検査方法として溶剤除去性染色浸透探傷法を選ん た. 表一 5 に探傷条件を示す．浸透探傷による亀裂検出 精度は, 主に浸透時間および現像時間に左右される.こ こでは，実橋部材の検査であることを考虑してそれぞれ $1 \mathrm{~h}, 5 \mathrm{~min}$ とした。ただし，微小亀裂については現像時 間をさらに長くし，12 時間後に判定することにした.

\section{表一5 漫透探傷試験条件}

\begin{tabular}{|c|c|}
\hline 前処理方法 & $\begin{array}{l}\text { エアゾールタイブ洗浄液 } \\
\text { 自然乾燥(15分)および } \\
\text { ドライヤーにて強制乾燥 }\end{array}$ \\
\hline 漫透液 & 溶剂除去性染色漫透液 \\
\hline 漫透処理方法 & ウエスでの拭き取り * \\
\hline 現像方法 & 速乾性 \\
\hline 試験面温度 & $10 \sim 18^{\circ} \mathrm{C}$ \\
\hline 漫透時間 & 1時間 \\
\hline 現像時間 & 5分 12時間 \\
\hline 観察方法 & 目視 \\
\hline
\end{tabular}

*本方法で除去出来なかった場合はウエスに 少鱆の洗浄液をつけて除去

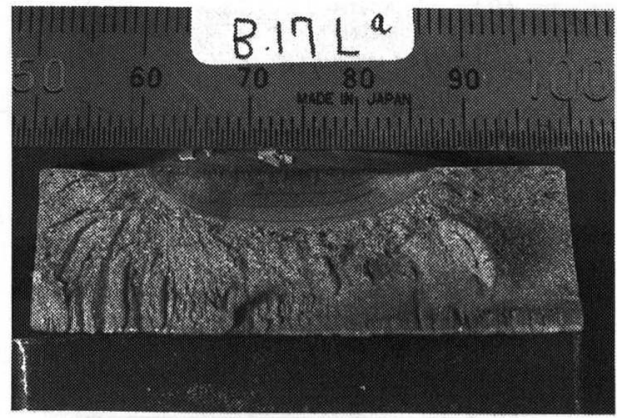

漫透探侮試硢

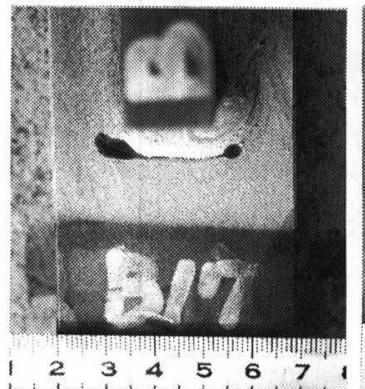

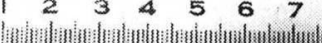

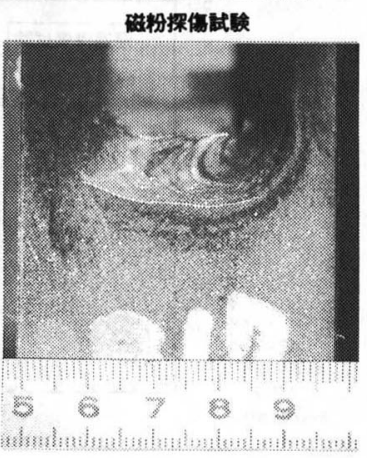

写真一4 代表的な量裂破面および探傷試験結果 


\section{（2）裂長さの推定}

写真一 4 に代表的な亀裂についての露呈破面および磁 粉探傷模様, 浸透探傷模様を示す.それぞれの探傷によ り亀裂表面長さを測定し, 実際の亀裂長さとの対応を検 討した。図一2に実亀裂長さと推定亀裂長さの関係を示 す. $\mathrm{A}$ 供試体， B 供試体についてそれぞれプロットし， 末検出の亀裂は黒塗りで示してある.なお, 隣接した亀 裂については, 連続した亀裂として評価した場合があり， これについては実亀裂寸法も2つの亀裂の両端部の寸法 （付表参照）をもって亀裂寸法としている.

磁粉探傷試験では一部を除いて両者が非常によく対応 している.今回の疲労亀裂の最小長さは $5 \mathrm{~mm}$ であり, これをほぼ正確に評価していることから, 検出限界長さ
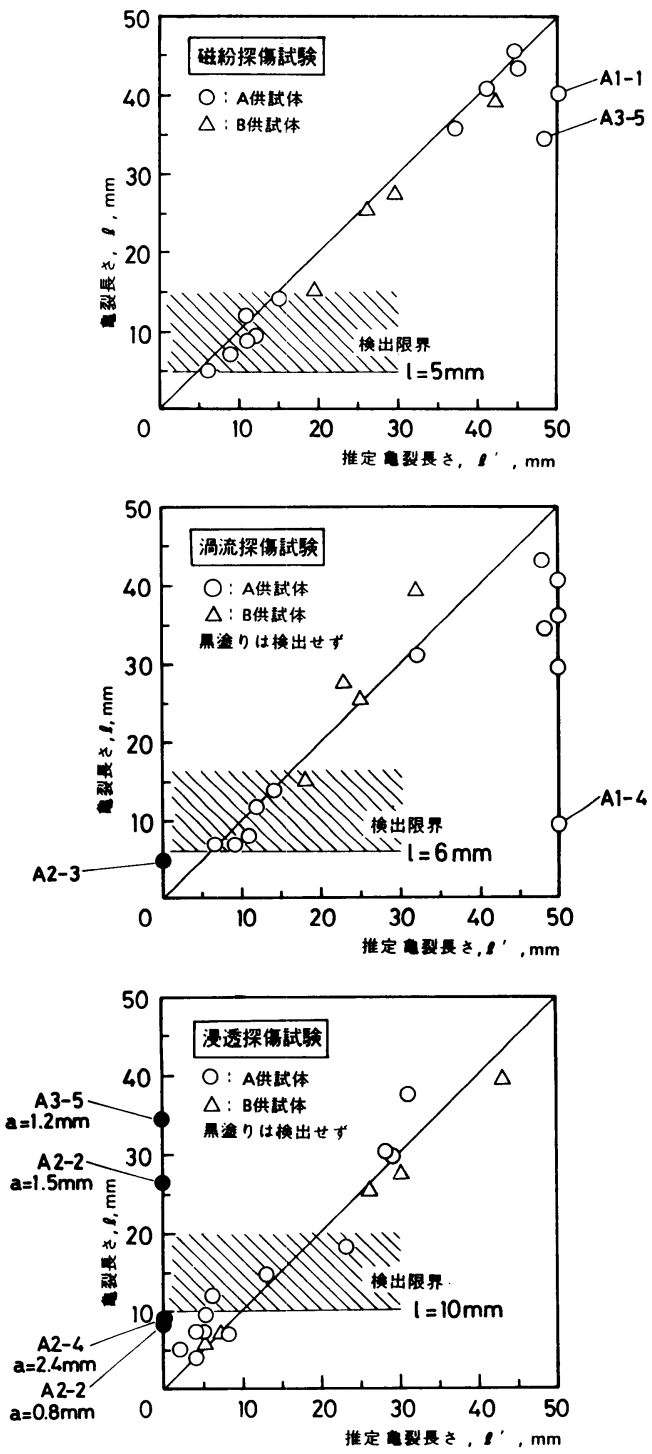

图一2 実裂長さと推定裂長さの関係
は $5 \mathrm{~mm}$ 以下と判断できる。ただし，マークを付した A 1-1，A 3-5 の 2つが過大評価となっている．いずれ も, 他の隅肉ビード止端部に比べて異常はなく, 微小な ひっかき疪のようなものが影響していたものと考えられ るが，実部材の隅肉溶接継手の止端部に発生する疲労亀 裂を検出しようとする場合にはこのような誤情報が十分 にあり得ることを示している.

渦流探傷試験においては，長さが $30 \mathrm{~mm}$ を越える亀 裂が過大評価となっている．いずれも亀裂が試験片端部 近傍まで進展しているものである．先に述べたように， 試験片端部では渦電流が乱れるために，この疑似信号を 亀裂信号と間違えて評価したものである，また，A 1-4 については止端部に微小アンダーカットが点在してお
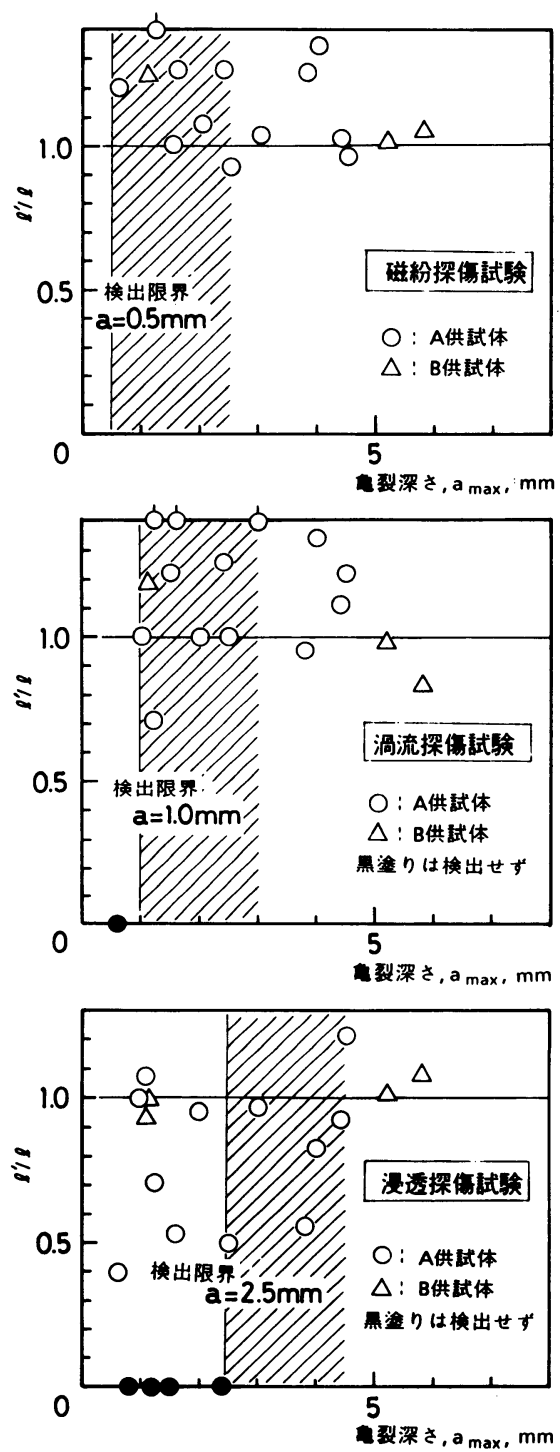

図一－裂深さに前目した裂検出限界 
り，これを亀裂と誤評価したものである：このように， 渦流探傷はアンダーカットおよび継手詳細に起因する疑 似信号の影響を受けるものの，亀裂長さが小さいものに ついてはA 2-3 ( $l=5 \mathrm{~mm})$ を除いていずれも検出して おり，検出限界は $6 \mathrm{~mm}$ 程度と判断できる.

浸透探傷では, 特に小さい亀裂において過小評価と なっている，亀裂が小さい場合には，開口幅が狭く，亀 裂面内への浸透液の浸み込みが十分でないためと推定で きる. 図中，未検出の亀裂について供試体マークと亀裂 深さを記したが, A 3-5 は $l=34.5 \mathrm{~mm}$ と表面が長い亀 裂であるにもかかわらず，亀裂深さが $1.2 \mathrm{~mm}$ と浅いた めに検出できなかった．このことは，現場での目視検査 において塗膜上の錆汁により亀裂の存在が予想されて も，浸透探傷試験では検出できない現象と同じである. 浸透探傷試験は装置の簡便さから広く用いられてきてい るが,他の探傷方法に比べて信頼性は高くないといえる.

\section{（3）表面电裂検出に対する电裂深さの影畒}

浸透探傷試験の場合，亀裂検出の可否は表面における 開口の程度に依存し，ここで対象としているような龟裂 の表面開口量は亀裂深さに関係する．磁粉探傷試験，渦 流探傷試験においても同様のことが考えられる．図一-3 は亀裂深さ $a$ に注目して寸法推定值を整理したものであ る.

磁粉探傷試験では $a=0.5 \mathrm{~mm}$ であっても検出可能で

\section{表一6裂検出限界および寸法推定精度}

\begin{tabular}{|c|c|c|c|}
\hline & \multicolumn{2}{|c|}{ 検出限界 } & \multirow{2}{*}{$\begin{array}{l}\mathrm{a} \leqq 5 \mathrm{~mm} \text { の } \\
\text { 裂の楧出 }\end{array}$} \\
\hline & $\rho$ & $\mathbf{a}$ & \\
\hline 磁紛探鹪 & $5 \mathrm{~mm}$ & $0.5 \mathrm{~mm}$ & 過大評価の㑯向 \\
\hline 㵝流探賃 & $6 \mathrm{~mm}$ & $1.0 \mathrm{~mm}$ & $n$ \\
\hline 漫透探稘 & $10 \mathrm{~mm}$ & $2.5 \mathrm{~mm}$ & 過小評価 \\
\hline
\end{tabular}

あり，わずかに過大評価の傾向にある. 渦流探傷試験で は $a=0.5 \mathrm{~mm}$ の亀裂は検出できず, $a=1 \mathrm{~mm}$ から検出 可能である. 一方浸透探傷試験では $a<2.5 \mathrm{~mm}$ の亀裂 の一部は検出されないことがあり, 検出されても過小評 価となっている．なお， A 供試体の亀裂 (○印) の場合， 前面隅肉溶接継手であることから亀裂の全線にわたって 止端部の形状, 材質変化の影響を受けやすく, 誤差が大 きい傾向にある. B 供試体においては回し溶接止端部 から亀裂が発生するものの, ある程度進展すれば隅肉溶 接部からはずれることから検出精度はよくなっている.

以上の結果をもとに表一6には 3 種類の非破壊試験に ついての亀裂検出限界をまとめて示す.さらに，いずれ も亀裂深さが大きいと比較的検出しやすいことから， $a \leqq 5 \mathrm{~mm}$ の亀裂についての長さ推定精度を合わせて示 した.

\section{4. 超音波探伤試験による裂深さの推定}

亀裂深さの測定が可能な非破壊試験としては数種類の 方法があるが,ここでは，探傷精度がよく，現場での検 查に適している超音波探傷端部エコ一法を採用した．深 さ推定にあたって，その検出能は使用探触子性能によっ て異なってくる.そこで, 試験に先立って種々の探触子 についての性能を調べるとともに，代表的な疲労亀裂に ついてその検出能を検討した.

\section{（1）探触子の選定}

使用した探触子の形状は汎用型(ノーマル), 点集束型, 分割型の 3 種類, 屈折角は $45^{\circ}, 60^{\circ}, 70^{\circ}$ である. 表一7 に代表的な探触子の性能と亀裂検出能を示す. 亀裂検出 能は, 写真一1にその露呈破面を示す比較的浅い亀裂 (A 2-3) と深い亀裂（A 2-1）について調べたものであ る. 探傷は図一 4 に示すように，亀裂面表裏より，それ

表一7 代表的な探触子の性能と重裂検出能力

\begin{tabular}{|c|c|c|c|c|c|c|c|c|c|c|c|c|c|c|c|c|}
\hline \multicolumn{3}{|c|}{ 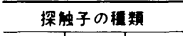 } & \multirow{3}{*}{$\begin{array}{c}\text { 接近限罪 } \\
\text { 長さ } \\
\text { mm }\end{array}$} & \multicolumn{3}{|c|}{ 分解能 } & \multirow{2}{*}{\multicolumn{2}{|c|}{$\begin{array}{l}S / N \\
C d B\end{array}$}} & \multicolumn{4}{|c|}{$2.5 \mathrm{~mm}$ の深さの琹検出 } & \multicolumn{4}{|c|}{$7.2 \mathrm{~mm}$ の深さの 玟検出 } \\
\hline \multirow{2}{*}{ 形式 } & \multirow{2}{*}{ 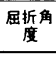 } & \multirow{2}{*}{\begin{tabular}{|c|} 
\#イर \\
$\mathrm{mm}$ \\
\end{tabular}} & & \multirow[b]{2}{*}{$\mathrm{adB}$} & \multicolumn{2}{|c|}{$D d B$} & & & \multicolumn{2}{|c|}{ 蜠面 } & \multicolumn{2}{|c|}{ 袁面 } & \multicolumn{2}{|c|}{ 喜面 } & \multicolumn{2}{|c|}{ 黄面 } \\
\hline & & & & & $0.5 \mathrm{~s}$ & 1.05 & $0.5 \mathrm{~s}$ & 1.05 & $0.5 \mathrm{~S}$ & 1.05 & $0.5 \mathrm{~S}$ & 1.05 & $0.5 \mathrm{~S}$ & 1.05 & 0.55 & $1.0 \mathrm{~S}$ \\
\hline \multirow{2}{*}{ 点集束 } & 45 & $10 \phi$ & 9.0 & 42 & 1.2 & 0 & 15 & 12 & $\mathrm{O}$ & $x$ & $\triangle$ & $x$ & $\mathrm{O}$ & $\mathrm{O}$ & $\triangle$ & $\mathrm{O}$ \\
\hline & 45 & $15 \phi$ & 15.0 & 44 & 1.2 & 0 & 19 & 18 & $\mathrm{O}$ & $x$ & $\triangle$ & $x$ & $\mathrm{O}$ & 0 & $\triangle$ & $\mathrm{O}$ \\
\hline \multirow{2}{*}{ 分輁 } & 45 & $4 \times 9$ & 10.0 & - & - & - & - & - & $\mathrm{O}$ & $x$ & $\triangle$ & $x$ & $\mathrm{O}$ & $\mathrm{O}$ & $\triangle$ & $\mathrm{O}$ \\
\hline & 60 & $4 \times 9$ & 6.0 & - & - & - & - & - & $\times$ & $x$ & $\triangle$ & $\times$ & $\mathrm{O}$ & $x$ & O & $\times$ \\
\hline \multirow{4}{*}{ 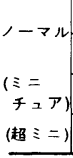 } & 45 & $10 \times 10$ & 12.0 & 46 & 0 & 1.2 & 6 & 10 & $\mathrm{O}$ & $x$ & $\triangle$ & $\times$ & $\mathrm{O}$ & $\mathrm{O}$ & $\triangle$ & 0 \\
\hline & 60 & $10 \times 10$ & 11.0 & 44 & 不可 & 不可 & 10 & 8.5 & $\times$ & $x$ & $\Delta$ & $\times$ & 0 & O & $\times$ & 0 \\
\hline & 45 & $6.35 \phi$ & 6.5 & 60 & 4.1 & 3.3 & 12 & 12 & $\mathrm{O}$ & $x$ & $\triangle$ & $x$ & $\mathrm{O}$ & $\mathrm{O}$ & $\mathrm{O}$ & 0 \\
\hline & 70 & $47 \times 4.7$ & 5.0 & - & - & - & - & - & $x$ & $\times$ & $\times$ & $\times$ & 0 & $x$ & $x$ & $\times$ \\
\hline & . & 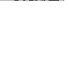 & 接近限界 & $\begin{array}{l}\text { STBA2 } \\
\phi 1.5 \times 4\end{array}$ & $\begin{array}{l}211 \\
0.2 \times 1\end{array}$ & & & & A2-3 & & & & $A 2-1$ & & & \\
\hline & & & & & & 5 & vi & $\begin{array}{l} \\
\end{array}$ & & & & & 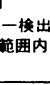 & & & \\
\hline
\end{tabular}

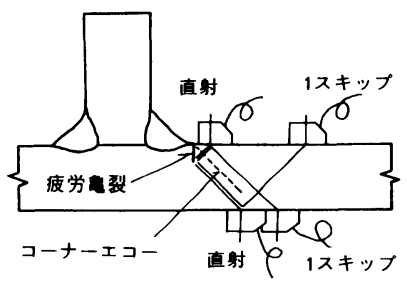

図一4 探䂓方法 

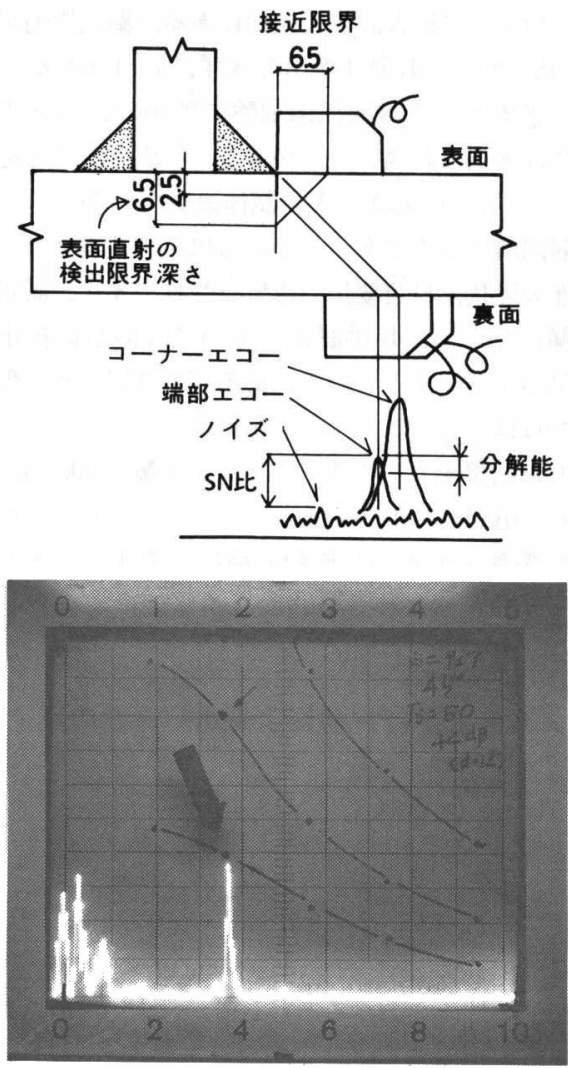

図一5 端部エコー法の概要 (A 2-3)

ぞれ直射法, 1 回反射法で行った. 図一 5 には端部エコー

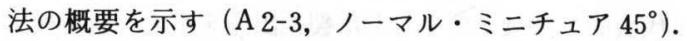
疲労亀裂を検出するにはできるかぎり多くの方向から探 傷した方が信頼性があるが, 表面側からの直射の探傷の 場合には接近限界の問題がある.接近限界は振動子寸法, 屈折角で決まるが, 浅い亀裂の場合にはほとんど接近限 界内となり, 亀裂検出が不可能である. さらに, 浅い亀 裂の深さを精度よく測定するには, コーナーエコーと端 部エコーをいかに分解するか $(\mathrm{adB})$, また, 両エコー が重なりあっても, 各エコー間に生ずる谷間 $(\mathrm{b} \mathrm{dB})$ によって決まる. 表からわかるように, このような分解 能についてはノーマル・ミニチュア・屈折角 $45^{\circ}$ が最も 優れている. さらに, 端部エコーとノイズとの分解も重 要であり $\left(\mathrm{C} \mathrm{dB}, S N\right.$ 比), これは点集束型・屈折角 $45^{\circ}$ が優れている. しかしながら, 図一5に示した探傷波形 からわかるように, 端部エコーの検出にはノーマル・ミ ニチュアの $S N$ 比でも十分である.

なお, 実際の橋梁では, 狭隘な場所に亀裂が発生する ことが多く, 探触子の走查可能範囲が限定され, 探触子 寸法の小さいことが要求される.このようなことから, 今回の試験では分解能が優れており, 接近限界長さの小

\section{表一8 使用装置および探傷条件}

\begin{tabular}{|c|c|}
\hline $\begin{array}{l}\text { 探 鹪 器 } \\
\text { 探 触 }\end{array}$ & 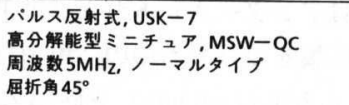 \\
\hline $\begin{array}{l}\text { 対比試験片 } \\
\text { 探倠感度 }\end{array}$ & $\begin{array}{l}\text { スリット試験片, } 0.2 \mathrm{~W} \times 1.0 \mathrm{H} \times 10 \mathrm{~L} \\
0.2 \mathrm{~W} \times 1.0 \mathrm{H} \times 10 \mathrm{~L} \text { 端部エコーが検出さ } \\
\text { れる感度を最低レヘルとし、実際の } \\
\text { 探傍においてノイスェコーがCRTで } \\
10 \% \text { 程度現れる感度 }\end{array}$ \\
\hline 接触媒需 & タリセリン水溶液 (濃度 $75 \%$ 以上) \\
\hline
\end{tabular}

さいノーマルタイプのミニチュア探触子(屈折角 $45^{\circ}$ ) を用いることにした．表一8には，試験に用いた機器お よび探傷条件を示す。

\section{（2）亀裂深さの推定}

図一6に実亀裂深さと超音波探傷による推定值との対 応を示す. 推定寸法は先の図一4に示したように主材表 裏各 2 方法の探傷を行い, 最大の指示深さとした.

$a \geqq 2.5 \mathrm{~mm}$ の場合, 推定値は実寸法と比較的よい対 応を示しており, 図中に亀裂マークを付した 3 点を除い て $\pm 1 \mathrm{~mm}$ の誤差範囲に入っている. 写真一 5 にB 6 の 亀裂破面を示す. 深さ測定点(C)ではょうど, 亀裂前縁 が急激に変化しており, 探触子の首振りを含めて位置情 報のわずかな誤差が過大評価につながったものと考えら れる. 写真一 6 には B 4 の亀裂の破面之浸透探傷模様を 示す. 亀裂は止端部に沿って発生しており, 亀裂の全線 が探傷方向に対して直角ではなく, 複雑な曲線を描いて いる. また，写真一7にこの位置での断面のマクロを示 すが, 亀裂は主材に対してわずかな傾きをもって進展し ている.このように隅肉溶接止端部に発生する亀裂は, 主材板面に垂直な平面ではなく, 屈曲した面を形成する ことがあり,このことが探触子位置, ビーム路程から推 定する亀裂端部位置の誤評価の原因になるものと考えら れる.

\section{（3）コーナーエコーの検出}

$a<2.5 \mathrm{~mm}$ の亀裂は, 亀裂と板表面にできるコーナー

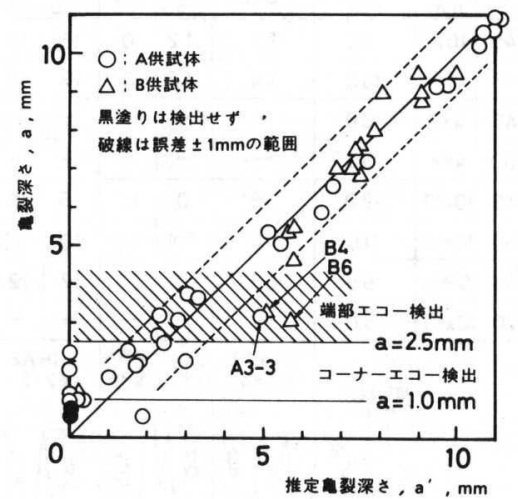

図一 6 実電裂深さと推定值との関係 

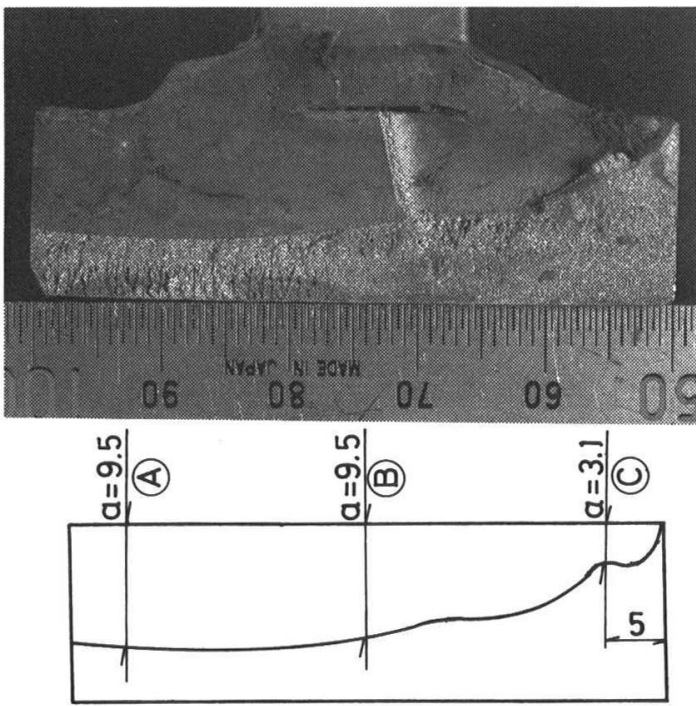

$\mathrm{I}=50 \mathrm{~mm}$ $a_{\max }=10.0 \mathrm{~mm}$

写真 5 量裂破面 (B-6)

部（図一5参照）からの反射エコーによりその存在は確 認できたが，亀裂端部エコーが識別できず，寸法推定が 不可能なことが多かった. 写真—8に深さ $1 \mathrm{~mm}$ の機械 スリット（探傷面に直角な幅 $0.2 \mathrm{~mm}$ の機械加工溝）と 疲労亀裂（B-5）のCRT 写真を比較して示す. 機械ス リットのコーナーエコー波形は単純であり，深さが 1 $\mathrm{mm}$ であれば端部エコーの識別が可能である.これに対 し, 疲労亀裂の場合には反射エコー波形が全体的に乱れ ており,コーナーエコーと端部エコーとの識別が困難で ある. 亀裂が深くなればブラウン管上での両者の距離が 大きくなり, 深さが $2.5 \mathrm{~mm}$ 以上になるとおのおのの識 別が十分に可能であるといえる.

図一7には亀裂深さとコーナーエコー高さの関係をプ

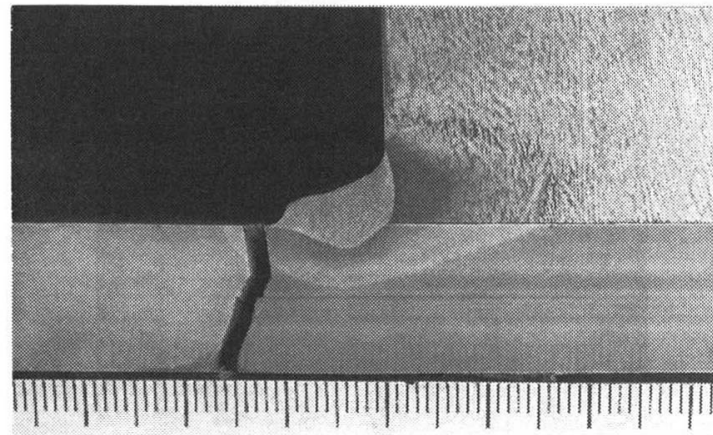

$$
\begin{array}{llllll}
3 & 4 & 5 & 6 & 7 & 8 \\
& \text { 写真 } 7 \text { - } & \text { 裂断面のマクロ }(\mathrm{B}-4)
\end{array}
$$

ロットする．機械スリットについては両者に比例関係が 成り立つことが知られているが12), 今回の疲労亀裂にお いては明確な関係がみられない. 写真一9には止端部全 線にわたって発生している亀裂の磁粉探傷模様を示す. 亀裂はビードの波目に沿うように発生しており，コー ナー部はビーム入射方向に対して必ずしも直角ではな い. さらに前述のように亀裂面では傾斜しているための 面反射の影響も考えられ，理想的な関係が得られないも のと考えられる.

\section{（4）㿞裂深さの寸法推定精度}

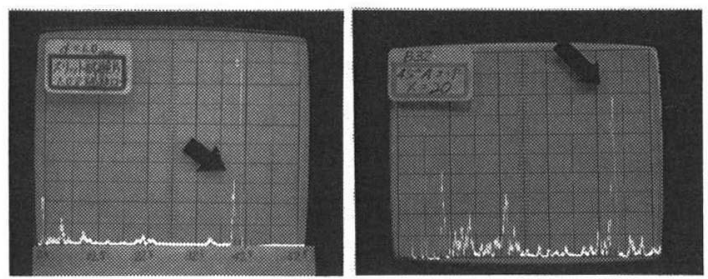

写真一8 機樴切欠きと疲労盘裂の探傷波形

(左：スリット試験片, 右：B-5 の疲労亀裂)
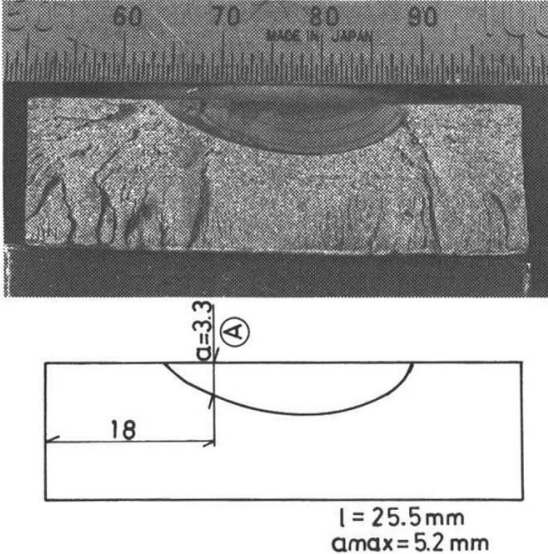

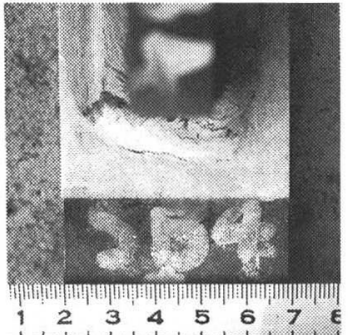

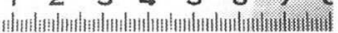

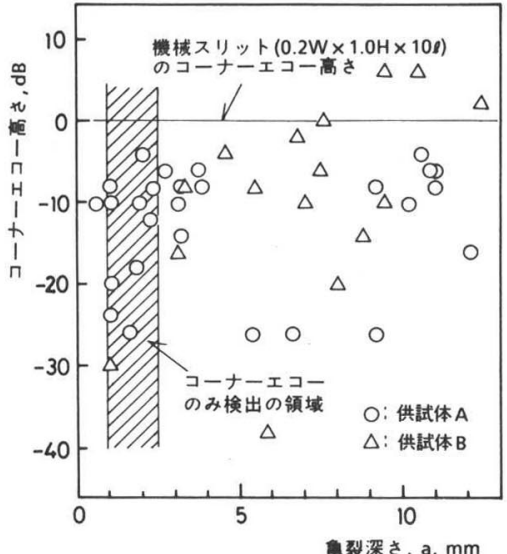

写真一6 裂破面と漫透探稘模様（B-4） 


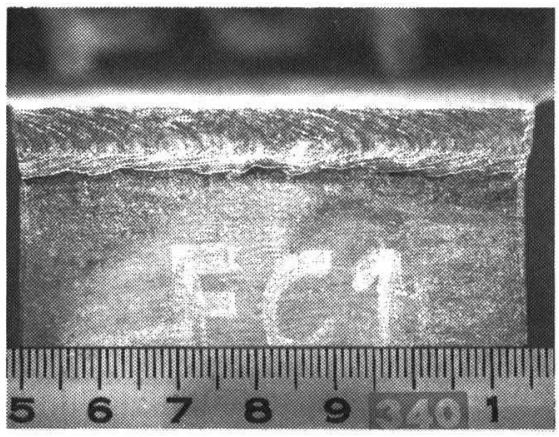

写真一9 奄裂表面の磁粉探傷模様

表一9 超音波探傷による香裂検出限界および精度

\begin{tabular}{l|c|c}
\hline & $\begin{array}{c}\text { 重裂深さ } \\
\text { 検出限界 }\end{array}$ & 寸法推定精度 \\
\hline コーナーエコーの検出 & $1 \mathrm{~mm}$ & 寸法推定不可 \\
\hline 端部エコーの検出 & $2.5 \mathrm{~mm}$ & $\pm 1 \mathrm{~mm}$ \\
\hline
\end{tabular}

図一において，黒塗りのプロットは超音波探傷によ り亀裂の検出ができなかったものである(A 2-2, $a=$ $0.8 \mathrm{~mm}$ および A 2-3, $a=0.6 \mathrm{~mm}$ ). 亀裂深さが $1 \mathrm{~mm}$ より小さい場合には端部エコー, コーナーエコーとも検 出が不可能であった. 表 9 には以上の結果をまとめて, 超音波探傷による亀裂深さの検出限界および寸法推定精 度を示す. 隅肉溶接止端部から発生する疲労亀裂はミク 口的な形状が複雑であるために機械スリットについて得 られる検出限界, 精度より悪くなるものの, 亀裂深さが $1 \mathrm{~mm}$ 以上であればその存在が確認でき, $2.5 \mathrm{~mm}$ 以上 ならば一部の例外を除いて $1 \mathrm{~mm}$ の誤差で寸法推定が 可能である.ただし，この数値は今回使用した探触子に ついてのものであり, 探傷器・探触子が異なれば若干の 変動が考えられる.

\section{5. まとめ}

隅肉溶接止端部から発生する疲労亀裂について各種非 破壊試験の適用性を検討した。非破壊試験による亀裂検 出限界は探傷条件によって大きく異なるため,ここでは 現場の作業性を考慮して最適な条件を選定した。試験結 果をまとめると以下のようである.

（1）磁粉探傷試験（蛍光湿式交流極間法）は長さ5 $\mathrm{mm}$, 深さ $0.5 \mathrm{~mm}$ の亀裂の検出が可能であり, 亀裂表 面長さの推定精度はわずかに過大評価となる。

（2）浸透探傷試験（溶剤除去性染色法）による疲労 亀裂検出はばらつきが大きく, 長さ $10 \mathrm{~mm}$, 深さ 2.5 $\mathrm{mm}$ より小さい亀裂は検出不可能の場合がある.

（3）渦流探傷試験 (単一法, プローブ径 $10 \mathrm{~mm} \phi$ )
は試験片端部の疑似信号, 微小アンダーカットの検出の ために一部過大評価となるが, 精度的には先の 2 つの探 傷方法の中間と考えられる.

（4）超音波探傷試験端部エコー法による亀裂深さの 測定は深さが $2.5 \mathrm{~mm}$ 以上であるならば可能であり，そ の推定精度は $\pm 1 \mathrm{~mm}$ である. また, 深さが $1 \mathrm{~mm}$ 以上 の亀裂については, 亀裂と板表面に生ずるコーナーから の反射エコーによりその存在が確認できる.

なお, 隅肉溶接継手に発生する亀裂は止端部の形状, 材質変化の影響を受け, 単純な平面ではなく複雑な面を 形成しているために, いずれの非破壊試験でも機械切欠 きのような理想的な欠陥と比べて検出限界, 寸法推定精 度が悪くなるものと考えられる.

\section{付表一1 供試体 A の龟裂寸法}

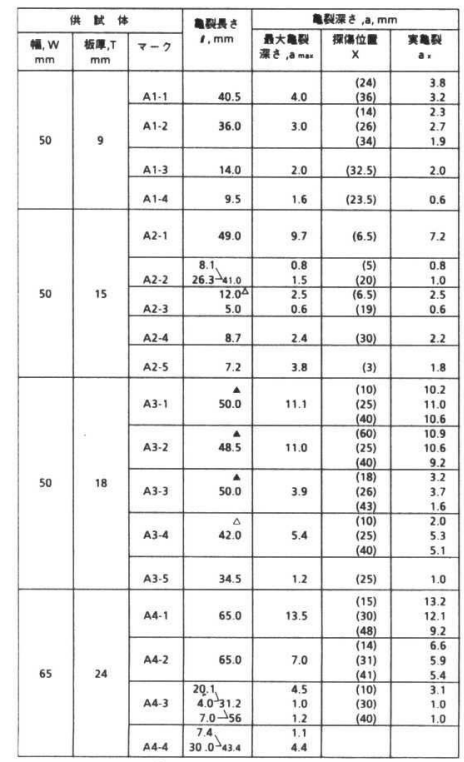

付表-2 供試体 B の愚裂寸法

\begin{tabular}{|c|c|c|c|c|c|}
\hline \multicolumn{2}{|c|}{ 供战体 } & \multirow{2}{*}{ 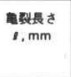 } & \multicolumn{3}{|c|}{ 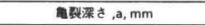 } \\
\hline 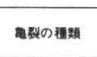 & $\nabla-7$ & & 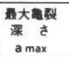 & 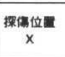 & 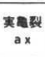 \\
\hline \multirow[t]{5}{*}{ 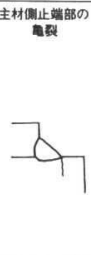 } & B1 & 44.6 & 9.1 & $\begin{array}{l}(10) \\
(25) \\
(30)\end{array}$ & $\begin{array}{l}7.0 \\
9.0 \\
9.0\end{array}$ \\
\hline & B2 & 39.7 & 9.0 & $\begin{array}{l}(14) \\
(25) \\
(40)\end{array}$ & $\begin{array}{l}7.6 \\
8.8 \\
6.8\end{array}$ \\
\hline & B3 & 27.7 & 5.8 & (25) & 5.5 \\
\hline & B4 & 25.5 & 5.2 & $\begin{array}{l}(18) \\
(33)\end{array}$ & $\begin{array}{l}3.3 \\
4.6\end{array}$ \\
\hline & 85 & $\begin{array}{l}7.0>^{15.3} \\
5.3\end{array}$ & 1.1 & (20) & 1.0 \\
\hline \multirow[t]{2}{*}{ 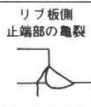 } & B6 & $50.0^{A}$ & 10.0 & $\begin{array}{l}(5) \\
(25) \\
(45)\end{array}$ & $\begin{array}{l}3.1 \\
9.5 \\
9.5\end{array}$ \\
\hline & B7 & $50.0^{A}$ & 9.7 & $\begin{array}{l}\frac{170)}{(10)} \\
(25) \\
(40)\end{array}$ & $\begin{array}{l}7.0 \\
7.5 \\
8.0\end{array}$ \\
\hline & \multicolumn{3}{|c|}{ 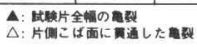 } \\
\hline
\end{tabular}




\section{参 考 文 献}

1）明石：溶接部疲労の現状と研究, 土木学会論文報告集, 第 350 号, 1984.10 .

2) 三木：構造物と安全性一疲労と安全, 土木技術, Vol. 38, No. 4, 1983.4.

3）西川：道路橋における疲労問題と補修・補強，橋梁と基 礎, Vol. 17, No. 8, 1983.8.

4) 阿部・谷口・阿部：鋼鉄道橋における疲労問題と補修 · 補強, 橋梁と基礎, Vol.17, No.8, 1983.8.

5）谷口・阿部・阿部：鉄道橋の疲労変状一垂直補剛材下端, 構造工学論文集, Vol. 33 A, 1987. 3.

6) Yazdani, N. and Albrecht, P. : Risk Analysis of Extending Bridge Service Life, 4th International Conference on Structural Safety and Reliability, 1985.

7) Kato, S., Yoshikawa, O., Terada, H. and Matsumoto, Y. : Studies on Fatigue Damages Based on Strain Measurements of Highway Bridge, Proc. of JSCE,
Vol. 2, No. 2, 1985. 10.

8) Fisher, J. W., Hausammann, H., Sullivan, M. D. and Pense A. W. : Detection and Repair of Fatigue Damage in Welded Highway Bridges, National Cooperative Highway Research Program Report 206, 1979.6.

9）三木 - 西川 - Fisher, J. W. : 鋼橋の疲労損傷とその検 查, 橋梁と基礎, Vol.20, No. 5, 1986.5.

10）藤盛：鋼溶接部の超音波斜角探傷試験における検出レベ ルについて, 日本建築学会大会学術講演梗概集, 1973. 10.

11）藤盛：鋼溶接部の超音波斜角探傷試験における久陥寸法 の推定方法について, 非破壊検査, 第 21 巻, 第 12 号, 1972. 12 .

12）仙田・三好・沢藤・鳥海・廣瀬・山本：溶接欠陥の検出 と形状判別に関する調査研究 (2)一従来法による欠陥の 評価の検討一, NDI 資料, No.2886, 1981.11.

(1987.4.23 - 受付) 